See discussions, stats, and author profiles for this publication at: https://www.researchgate.net/publication/324576289

\title{
Stakeholder pressures, CSR practices, and business outcomes in Denmark, Germany and the Netherlands
}

Article in European Journal of International Management · January 2018

DOI: 10.1504/EJIM.2018.10012423

CITATIONS

2

6 authors, including:

Olivier Furrer

Université de Fribourg

165 PUBLICATIONS 3,219 CITATIONS

SEE PROFILE

Some of the authors of this publication are also working on these related projects:

Project Corporate Social Responsibilities View project

Cultural Intelligence View project
READS

339

Dirk Holtbrügge

Friedrich-Alexander-University of Erlangen-Nürnberg

240 PUBLICATIONS 2,354 CITATIONS

SEE PROFILE 


\title{
Stakeholder pressures, CSER practices, and business outcomes in Denmark, Germany, and the Netherlands
}

\begin{abstract}
This cross-country study investigates the antecedents and outcomes of corporate social and environmental responsibility (CSER) practices. Based on institutional theory and stakeholder theory we conducted an empirical study among 519 firms in Denmark, Germany, and the Netherlands. We found evidence supporting a significant positive relationship between stakeholder pressures, CSER practices, and business outcomes in the total sample. While our data reveals similarities between the three countries, thus supporting the assumption of a panEuropean approach of CSER, differences in some areas can be observed as well. Implications for institutional theory and for CSER are derived.

Keywords: institutionali theory; stakeholder theory; corporate social and environmental responsibility
\end{abstract}




\section{INTRODUCTION}

It is widely accepted that the success of a firm does not only depend on its ability to meet customer demands but also on its relationship with various other stakeholders such as suppliers, financial institutions, governments, and. In particular, the stakeholder approach argues that a firm needs the support of all legitimate stakeholders that are affected by its operations. Thus, understanding different stakeholder group interests and their pressures on managerial decisions and practices is crucial for organizational success.

In recent years, several authors have argued that firms are faced with increasing stakeholder demands for responsible social and environmental behavior in addition to maximizing economic shareholder value. Consequently, firms have responded to these stakeholder pressures by implementing corporate social and environmental responsible (CSER) practices (Egri and Ralston, 2008). By CSER we mean all clearly orientated and communicated policies and practices of firms that reflect business responsibility for the wider societal and ecological good (Matten and Moon, 2008).

While the concept of CSER is well established, its relevance has increased as a result of growing public concerns about business' role in addressing environmental issues such as global climate change, renewable energies or nuclear energy (Brewer, 2008). Moreover, the current global economic crisis has highlighted business' responsibility for social outcomes of their operations such as their impact on labor markets (e.g., Peters, 2009) and poverty reduction (Prahalad, 2006). Therefore, it is not surprising that many prominent firms have implemented CSER practices as a key part of their business strategy.

Despite the increase in business globalization, there has been relatively little crossnational empirical research investigating country differences in respect to the antecedents and 
outcomes of CSER practices (see the literature reviews of Aguinis and Glavas, 2012; Egri and Ralston, 2008; Holtbrügge and Dögl, 2012). Previous cross-national CSER studies have focused mainly on comparisons between countries with obvious diverse institutional frameworks such as Europe and the U.S. (Doh and Guay, 2006; Maignan and Ralston, 2002). Differences between these countries are often explained by historically developed institutional frameworks under which firms operate. The liberal market economy and the tradition of corporate philanthropy in the U.S. leave a larger share of corporate responsibility issues to the discretion of individual firms. Moreover, there are more incentives and opportunities for them to take explicit responsibility. European firms perceive comparatively narrow incentives and opportunities. Their social and environmental activities are regulated by institutional and legal frameworks which reduce the need to explicitly communicate CSER activities. Thus, their CSER strategies are more implicit in contrast to the U.S. approach of explicit CSER (Matten and Moon, 2008; Rasche, 2015).

While the concept of explicit and implicit CSER has gained much attention in recent literature (e.g., Angus-Leppan, Metcalf, and Benn, 2010; Hiss, 2009; Sison, 2009), it has also been criticized for being too simplistic. Authors observe a general shift towards a more explicit CSER in Europe which is reflected by significant changes in the financial system, labor market and educational system and driven particularly by supranational organizations such as the European Commission (Ungericht and Hirt, 2010). At the same time, there exist large historic and abiding differences among and even within European countries (Habisch et al., 2005; Furrer et al., 2010). For example, Midttun, Gautesen, and Gjølberg (2006) and Jackson and Apostolakou (2010) find significant differences between the Anglo-Saxon, Continental, Nordic, and Mediterranean clusters. Moreover, there is evidence that European firms pursue similar 
approaches in some CSER areas while in other areas differences pertain. For example, sustainable HRM practices in Germany differ remarkably from those in other European countries (Preuss, Haunschild, and Matten, 2009), while a convergence of sustainability reporting can be observed (Kolk, 2008). As a consequence, Matten and Moon (2008: 419) call for 'more finegrained comparisons' in cross-national CSER research.

The purpose of this study is to analyze the impact of stakeholder pressures on CSER practices and outcomes and to reveal potential similarities and differences among European countries. We address these questions by focusing on the antecedents, prevalence, and outcomes of CSER practices in Denmark, Germany, and the Netherlands. These three countries have long been members of the EU with similar democratic welfare states, low corruption levels, civil legal systems, and high economic development levels. At the same time, they are characterized by remarkable differences with regard to their financial, labor and ecological systems. Thus, they represent an ideal background to test whether CSER in Europe follows a pan-European approach or whether institutional differences between European countries lead to differences in CSER.

Based on these considerations we seek answers to three research questions: (1) What are the similarities and differences in stakeholder pressures, CSER practices and business outcomes between Denmark, Germany, and the Netherlands? (2) To what extent are perceived stakeholder pressures related to the implementation of CSER practices? (3) To what extent do CSER practices lead to positive business outcomes? To answer these three research questions, we use institutional theory and stakeholder theory. Institutional theory has been frequently applied to analyze CSER issues and emphasizes the relevance of isomorphic pressures on firm behavior. Stakeholder theory, on the other hand, argues that firms need to consider the interests of all legitimate stakeholders in order to realize their goals 
The remainder of this paper is organized as follows. First, the main arguments of institutional theory and stakeholder theory with regard to CSER are outlined and research hypotheses concerning stakeholder pressures, CSER practices, and business outcomes are developed. Then the methodology of the study is explained, followed by the presentation and discussion of its results. In the final section, the main contributions of the study as well as its implications and limitations are presented.

\section{THEORY AND HYPOTHESES}

Institutional theory emphasizes the role of social and cultural pressures imposed on firms that influence its practices and structures (Scott, 1992). Because stakeholder pressures are tied to and interdependent with the surrounding institutional environments, institutional theory is often used to analyze CSER issues (e.g., Doh and Guay, 2006; Greening and Gray, 1994; Jennings and Zandbergen, 1995; Marquis et al., 2007; Matten and Moon, 2008). According to institutional theory, firms respond to stakeholder pressures as their survival depends on compliance with expectations from regulative, normative, and cognitive/cultural institutional environments (DiMaggio and Powell, 1983; Meyer and Rowan, 1977). In the context of institutional theory, a firm's stakeholders play a decisive role in exerting isomorphic pressures on firms to adopt practices with environmental and social value.

Institutional pressures imposed on firms often result in structural homogeneity. Firms operating in institutionally homogenous environments interact with each other more easily and coordinate their activities more effectively than firms in heterogeneous institutional environments. Institutional isomorphism is especially distinct in highly developed countries and leads to competition among firms for political power, institutional legitimacy, economic power, and social as well as environmental strength. Firms that are able to reduce this institutional 
pressure by complying with stakeholder demands are therefore able to increase their reputation and financial performance (DiMaggio and Powell, 1983).

Three forms of institutional isomorphism can be distinguished with regard to CSER, namely coercive, mimetic and normative pressures (DiMaggio and Powell, 1983). Coercive pressures result from political strategies and initiatives to boost the spread of CSER practices. These are, for example, regulatory and optional initiatives like codes of conduct issued by national governments as well as supranational and international institutions, such as the UN, OECD, ILO, and Global Reporting Initiative (Kolk, 2008). Moreover, coercive pressures can be imposed by non-governmental organizations (NGOs) which pursue social (e.g., trade unions) or environmental issues (e.g., Greenpeace). Mimetic pressures can occur in the form of best practices which are regarded as legitimate in an organizational field. For example, competitors in the same industry are likely to exhibit strong conformity and imitation pressures. Normative pressures are associated with professionalization and can be imposed, for example, by industry associations or educational authorities that set standards for legitimate CSER practices.

\subsection{Stakeholder pressures in Denmark, Germany, and the Netherlands}

Based on the considerations of Matten and Moon (2008) we argue that firms in Denmark, Germany, and the Netherlands are faced with similar pressures from their institutional environment as they are all member countries of the EU. In particular, the European Commission imposes strong coercive pressures by setting standards and introducing initiatives to boost the spread of CSER practices. Social issues have been relevant in the EU since its foundation in 1957 and include creating growth and jobs in a sustainable manner, preserving workers' rights and social protection, encouraging corporate social responsibility, and providing equal opportunities (European Commission, 2007). Moreover, the European Social Charter from 1961 
seeks 'to make every effort in common to improve the standard of living and to promote the social well-being of both their urban and rural populations by means of appropriate institutions and action.' The first environmental policy of the EU was launched in 1972 and later institutionalized by the European Environment Agency. These initiatives are often directly put into national legislation and are thus perceived as strong coercive pressure by European firms for the implementation of CSER practices (Habisch and Wegner, 2005).

We can also see similar mimetic pressures for CSER as more and more European firms join business coalitions, such as CSR Europe, a multi-stakeholder forum to provide a platform for CSER on a European level set up by the European Commission in 2002 (CSR Europe, 2007). Another important initiative is the EU's Eco-Management and Audit Scheme (EMAS) that is designed for companies and other organizations committing themselves to evaluate, manage and improve their environmental performance. Moreover, the diffusion of standardized CSER reports among European firms increases due to shareholder pressure and best-practice sharing (Kolk, 2005). Based on these considerations we propose:

Hypothesis 1. There are no significant differences between Denmark, Germany, and the Netherlands with regard to the perceived primary and secondary stakeholder pressures for corporate social and environmental responsibility.

\subsection{Stakeholder pressures and CSER practices}

Our second research question focuses on the extent to which perceived stakeholder pressures are related to the implementation of CSER practices and whether this relationship is consistent across Europe. In the existing literature it is often distinguished between primary (market-based) and secondary (non-market) stakeholder groups (Clarkson, 1995; Holtbrügge, Berg, and Puck, 
2007). Primary stakeholders are directly affected by a firm's decisions and actions. Major primary stakeholders include customers, employees, financial institutions, and suppliers. Without creating value for these stakeholders by satisfying their demands and expectations, a firm cannot succeed or survive. Secondary stakeholders are entities that are not engaged in market transactions with the firm but are affected by its activities and can influence firms by, for example, regulating their environment or by influencing the public opinion. Major secondary stakeholders include government regulators/legislators, local communities, mass media, NGOs, and industry/trade associations.

With reference to primary stakeholders we argue that firms in European countries which act irresponsibly, e.g., by neglecting environmental protection or community needs, have more difficulties finding investors. Moreover, qualified employees will prefer working for firms that more fully meet their social and environmental expectations (Buysse and Verbeke, 2003). Customers may also pressure firms to offer products and services embodied with socially responsible and environmental friendly features and may boycott products of those firms which are not willing to do so. For example, Boiral (2007) and Jiang and Bansal (2003) find that persuasive customer demands are a major force for firms to adopt ISO 14001 certifications. Thus, we propose:

Hypothesis 2a. Perceived primary stakeholder pressures are positively related to the implementation of community $C R$ and environmental CR practices.

Not only shareholders, employees, and customers, but also secondary stakeholders gain coercive and normative (i.e. ethically appropriate) power and demand more attention of firms to non-economic aspects of their living conditions. Governments, local communities, and industry associations have several coercive mechanisms to pressure firms to act socially responsibly, e.g., 
through building permissions, traffic infrastructure, higher promotion for economic development and more liberal negotiation positions. Also public and social movement organizations can pressure firms to adopt CSER practices and to consider non-economic aspects, e.g., by sponsoring local events or by supporting charitable and educational organizations (Campbell, 2007; Doh and Guay, 2006).

Navarro (1988) states that firms which contribute to the safety of the community in which they are located may reduce the risks of theft and vandalism. This is often sustained by the media, who can pressure firms by reporting in a positive or negative way about a firm's community $\mathrm{CR}$ or environmental $\mathrm{CR}$ practices and thereby influence the public opinion positively or negatively.

With regard to environmental CR practices, governments and local communities can implement environmental directives and force firms to increase environmental protection in their business activities (Rugman and Verbeke, 1998). Studies have found that decisions of firms to adopt environmental CR practices are influenced by the desire to improve or maintain relations with their communities (Florida and Davidson, 2001). Also environmental organizations can activate public opinion in favor of or against a firm's environmental CR practices. For example, a study of Kassinis and Vafeas (2006) revealed that membership in communal environmental organizations leads to significant reductions of toxic emissions of plants in that community. Hence, we propose:

Hypothesis $2 b$. Perceived secondary stakeholder pressures are positively related to the implementation of community $C R$ and environmental $C R$ practices. 


\subsection{CSER practices in Denmark, Germany, and the Netherlands}

In line with our previous considerations we argue that firms in Denmark, Germany, and the Netherlands are faced with similar institutional and stakeholder pressures which lead to a low cross-national variation and more implicit forms of CSER practices. As member states of the EU, firms in these countries perceive relatively few incentives and opportunities to take responsibility (Matten and Moon, 2008). Instead, the European Commission and other supranational institutions are regulating CSER practices in the form of green papers and provisions that are often put into national legislation. As a consequence, the social and environmental policies of the EU members converge. For example, the Environmental Sustainability Index (ESI), that benchmarks the amount in which countries protect the environment in the past and their present position to sustain positive environmental conditions in the future, reveals close similarities between Denmark (ranked 26th), Germany (31st), and the Netherlands (40th) (Yale Center for Environmental Law and Policy \& Center for International Earth Science Information Network Columbia University, 2005).

A similar isomorphic pressure is imposed by firms' codes of conduct. Due to the high degree of intra-European trade they often have a pan-European scope and are applied in a standardized form across the whole continent. For example, many codes of conduct of European firms refer to the compliance with state created governance codes (Bondy, Matten, and Moon, 2004). As a consequence, a firm's discretion for CSER practices is limited. These considerations lead us to the following hypothesis:

Hypothesis 3. There are no significant differences between Denmark, Germany, and the Netherlands with regard to the implementation of community $C R$ and environmental $C R$ practices. 


\subsection{CSER practices and business outcomes}

In this section, we examine questions concerning whether corporate responsibility pays off and if there is cross-national consistency in the relationship between CSER practices and business outcomes. Using institutional theory arguments, Husted and Allen (2006) found that firms responding to stakeholder demands to implement CSER practices will be accorded higher legitimacy. This in turn is an important prerequisite for positive corporate reputation and financial performance (McWilliams and Siegel, 2001).

Fombrun and Shanley (1990) define corporate reputation as the cumulative judgments of a firm's stakeholders. It is determined by the signals that the public receives concerning its practices, whether directly from the firm or via other information channels, such as the media or the stock market (Brammer and Pavlin, 2006). According to Chatterji and Toffel (2010), CSER practices enable the building, maintenance, and assurance of corporate reputation. The more a firm is committed to a community and engaged in environmental protection, the more positive its image and publicity is. Previous research also suggests that there is a positive relationship between a company's CSER activities and consumers' attitudes toward that company (Brown and Dacin, 1997; Sen and Bhattacharya, 2001). Also the relationships between a firm and NGOs can be improved by CSER practices, e.g., by social work and community programs.

Community CR and environmental CR practices are also important aspects of a firm's employer image, i.e. firms with pronounced CSER practices are more attractive for employees than other firms (Collier and Esteban, 2007). Moreover, they improve employee satisfaction and reduce fluctuation. More and more financial institutions have started to demand CSER practices such as social auditing. NGOs and the media can influence the image of a firm by reacting to its community and environmental engagement or misbehavior in a positive or negative way. A 
prominent example for negative reporting in the mass media is Shell, whose behavior in the Brent Spar affair led to widespread consumer boycotts. The same applied to Bayer in the Lipobay/Bacol disaster. On the other hand, firms with good corporate reputations are supported by positive reports in the media, e.g., reports about CSER practices in favor of relevant stakeholders. Based on these considerations we propose:

Hypothesis $4 a$. Community $C R$ and environmental CR practices are positively related to corporate reputation.

Empirical research investigating the relationship between CSER practices and business outcomes shows mixed results. While some studies find positive correlations (Brammer and Millington, 2008; Flammer, 2013; Waddock and Graves, 1997), others indicate non-significant (McWilliams and Siegel, 2001) or even negative relationships (Wright and Ferris, 1997) (for an overview, see the meta-analysis of Orlitzky, Schmidt, and Rynes, 2003).

With regard to institutional theory it may be argued that firms which conform to institutional pressures show better financial results than those that neglect these pressures. Firms that adjust to their institutional environment interact more easily with their stakeholders and coordinate their activities more effectively. Moreover, the consideration of stakeholder expectations can lead to more efficient processes, improved productivity and lower costs of compliance (e.g., Russo and Fouts, 1997). Therefore, we propose:

Hypothesis $4 b$. Community $C R$ and environmental $C R$ practices are positively related to financial performance. 


\subsection{Business outcomes of CR practices in Denmark, Germany, and the Netherlands}

Do the isomorphic pressures of supranational institutions to implement CSER practices in Denmark, Germany and the Netherlands also lead to similar business outcomes? Based on institutional theory we argue that there may be no country influences expected. European institutions regard CSER not only as beneficial for the society and the environment, but also for the financial performance of firms. For example, the European Parliament emphasizes that 'the EU debate on CS[E]R has approached the point where emphasis should be shifted from process to outcome.' Consequently, CSER is regarded as a business opportunity which contributes to EU policies for growth, competitiveness, better jobs and sustainable development (CSR-IMPACT, 2010). Therefore, we propose:

Hypothesis 5a. There are no significant differences between Denmark, Germany, and the Netherlands with regard to the positive relationship between CSER practices and corporate reputation.

Hypothesis 5b. There are no significant differences between Denmark, Germany, and the Netherlands with regard to the positive relationship between CSER practices and financial performance

\subsection{Interaction effects between social and environmental CR practices and business outcomes}

While the social and ecological consequences of firms have often been discussed separately, recent research argues that these two aspects of CSER are interrelated (Egri and Ralston, 2008). Historically, social issues have been relevant in the EU since its foundation in 1957, while environmental concerns appeared in the early 1970s as a response to the first oil crisis and 
growing economic wealth. As Inglehart (1997) argues, once a country obtains a reasonably high level of economic welfare, citizens would finally be comfortable enough to fulfill their less basic concerns such as quality of life and the environment. Thus, post-industrialization led to a growing number of individuals in Europe that are becoming more socially responsible and environmentally concerned in terms of their personal habits and lifestyles.

The concurrence of social and ecological issues is also reflected by changes in the institutional environment of European firms. For example, Germany was ruled by a coalition between the Social Democratic Party and the Green Party between 1998 and 2005 which considered social and ecological issues as equally relevant. A similar tendency can be observed among NGOs. Traditionally, most NGOs have focused on a specific issue. However, when they grow in size, they tend to expand their activities to areas surrounding their original focus and become multi-issue NGOs. An example of the convergence of social and eco-labels to multiissue labels is Fairtrade International which certifies firms that guarantee sustainable social, environmental, and economic standards at the same time (de Boer, 2003). Similarly, Oxfam is committed to both social (e.g., education, gender equality and poverty reduction) and ecological issues (e.g., climate change).

With regard to institutional theory we argue that major stakeholders of firms in Denmark, Germany, and the Netherlands follow social and ecological aims in equal measure. There is strong coercive, mimetic and normative pressure on firms to consider not only the social impacts of their activities but also the ecological footprint they leave. Firms that implement community $\mathrm{CR}$ and environmental CR practices are therefore expected to be more successful in terms of corporate reputation and financial outcomes than firms that emphasize only one of these practices. This leads to the following hypothesis: 
Hypothesis 6. There is a synergetic effect between the implementation of community and environmental CR and business outcomes.

The research hypotheses that will be tested in this study are illustrated in Figure 1.

Insert Figure 1 about here

\section{METHODOLOGY}

\subsection{Sample and procedures}

We conducted a cross-sectional survey of firms in Denmark, Germany, and the Netherlands with country samples identified from the Dun \& Bradstreet Global Million Dollar database. Firms with fewer than 50 employees were excluded from the sampling frame. Of the remaining firms, a random sample of 1,500 firms was selected for each country. Questionnaire surveys were addressed to the most senior corporate executive (Chairman, CEO, CFO) named in the Dun \& Bradstreet database. Each survey questionnaire was sent with a cover letter, a self-addressed return envelope, and an offer for respondents to receive a summary of study findings (interested respondents were asked to send their business card in a separate envelope). Approximately three weeks after the first mailing, a reminder mail was sent to all firms in the sample. In total, 201 Danish firms, 138 German firms, and 180 Dutch firms responded to the survey. After accounting for undeliverable surveys, the response rates were, respectively, $14 \%, 10 \%$, and $15 \%$, which are comparable to mail survey response rates for top executive respondents (Cycyota and Harrison, 2006; Yang, Wang, and Su, 2006). 
The survey was initially designed in English and standard translation/back-translation procedures were used for each survey questionnaire. In each country, the survey questionnaire was pretested with a sample of 20 to 30 managers and business academic colleagues.

\subsection{Measures}

Stakeholder pressures. We identified 12 stakeholder groups from previous stakeholder research (Clarkson, 1995; Maignan and Ferrell, 2003; Waddock et al., 2002) and asked respondents to rate the pressures of each stakeholder group on their organizations to consider social and environmental issues using a five-point Likert scale $(1=$ very high importance; $5=$ very low importance; then reverse-coded). The initial exploratory factor analysis (EFA) for the total sample showed two sets of stakeholder groups: 6 primary stakeholders (corporate management, customers, employees, financial institutions, shareholders, and suppliers) and 6 secondary stakeholders (competitors, government regulators/legislators, industry/trade associations, local communities, mass media, and non-governmental organizations/interest groups (NGOs)). Two stakeholder items (industry/trade associations and shareholders) cross-loaded on both factors, and were therefore excluded. Multi-group confirmatory factor analyses (CFA) for the three countries showed cross-national configural invariance for a 4-item primary stakeholder scale (excluding corporate management) and a 4-item secondary stakeholder scale (excluding competitors) $\left[\chi^{2}{ }_{(68)}=113.35, \mathrm{p}=0.0005, \mathrm{CFI}=0.955, \mathrm{NNFI}=0.944, \mathrm{RMSEA}=0.066\right]$.

CSER practices. We identified six items to measure community CR practices (Clarkson, 1995; Maignan and Ferrell, 2003), and six items relating to environmental CR practices were developed from the proactive corporate environmental management literature (Egri and Hornal, 2002; Sharma, 2000). Respondents were asked to indicate the extent to which their organization had systematically adopted each CR practice using a 9-point Likert scale $(1=$ strongly disagree, 
to $9=$ strongly agree). The initial EFA for the total sample identified a 5-item community CR factor and a 5-item environmental CR factor. Multi-group CFA for the three countries showed cross-national configural invariance for the two 5-item CR practices scales $\left[\chi^{2}{ }_{(122)}=314.49, \mathrm{p}<\right.$ $0.00, \mathrm{CFI}=0.943, \mathrm{NNFI}=0.948, \mathrm{RMSEA}=0.095]$

Business outcomes. Financial performance was measured with a 5-item scale (adapted from Samiee and Roth, 1992; Maignan et al., 1999) that asked respondents the extent to which their organization's financial performance had been substantially better than their most relevant competitors over the past three years (using a 9-point Likert scale with $1=$ strongly disagree to 9 $=$ strongly agree). We measured corporate reputation with four items adapted from Fombrun et al. (2000) using a 9-point Likert scale ( $1=$ strongly disagree and $9=$ strongly agree). The total sample EFA showed scale items loading on to their respective factors, and the multi-group CFA for the three countries showed cross-national configural invariance for a 4-item corporate reputation scale and a 5-item financial performance scale $\left[\chi^{2}{ }_{(89)}=267.75, p<0.00, \mathrm{CFI}=0.939\right.$, $\mathrm{NNFI}=0.926, \mathrm{RMSEA}=0.089]$

Control variables. Given that perceived stakeholder pressures, CSER practices, and business outcomes may be influenced by firm-level variables, we included organizational characteristics as covariates in analyses. These included: internationalization $(1=$ multinational firm operating in two or more countries; $0=$ domestic-only); ownership form $(1=$ publicly traded; $0=$ privately held and other); company size $(1=$ fewer than 100 employees, $2=100-999$ employees, $3=$ more than 1,000 employees $)$; primary industry type $(1=$ services, $0=$ manufacturing and resource-based). 


\subsection{Analyses}

Measurement model. We conducted a number of statistical analyses to determine the convergent and discriminant validity of the measurement model. To determine the cross-national measurement invariance for the six scale variables, we conducted a series of multi-group CFAs (Steenkamp and Baumgartner, 1998). When examining model fit indictors, we focused on model fit indices (CFI, NNFI, RMSEA) that are not systematically influenced by sample size, i.e., Chisquare test statistics (Bagozzi and Yi, 1988; Cheung and Rensvold, 2002). While most coefficients were within an acceptable range, the multi-group CFA testing for measurement error invariance showed a change in the $\mathrm{CFI}$ statistic $(\triangle \mathrm{CFI}=0.019)$ that was above Cheung and Renvold's (2002) 0.01 cutoff level $\left[\chi^{2}{ }_{(978)}=1638.29, \mathrm{p}<0.00, \mathrm{CFI}=0.908, \mathrm{NNFI}=0.900\right.$, $\mathrm{RMSEA}=0.073 ; \Delta \mathrm{CFI}=0.019]$. The fact that cross-national metric invariance was not observed could be attributed to cross-cultural differences in scale response styles (Fischer, 2004; Johnson et al., 2005). Hence, we used Hanges and Shteynberg's (2004) procedure which involved regressing within-subject standardized scores on to raw scale scores and then retaining the scale scores adjusted for overall scale response style. The adjusted country means, standard deviations, and scale composite reliabilities (Raykov's $\rho$ ) for the six scale variables used in this study are presented in Table 1. The scale composite reliabilities (Raykov's $\rho$ ) were higher than the 0.70 thresholds (Bagozzi and Yi, 1988) with the exception of the two stakeholder pressure scales for Denmark which were both $\rho=0.64$.

Insert Table 1 about here

Common method variance may be an issue in studies relying on self-reported survey data (Podsakoff et al., 2003). To address this potential issue, we took preventive measures including: 
assuring anonymity and confidentiality to study participants; using measures found to be valid and reliable by previous research; using different descriptive scale anchors for various measures; and presenting items to measure variables in separate sections. In addition, we conducted a series of CFAs to test for common method variance using the combined total sample. Moreover, we applied a CFA marker technique proposed by Williams, Edwards, and Vandenberg (2003). For the marker variable that is theoretically unrelated to the study constructs, we used a 2-item 'personal satisfaction' scale that asked respondents to indicate the extent to which they were satisfied with their 'job in general' and their 'life in general. The model fit results with scale items loading on to their respective 7 factors were not significantly better than for the CFA model in which study scale items were also loaded on to the personal satisfaction marker factor. In summary, these analyses indicate sufficient convergent and discriminant validity to address concerns regarding common method bias influencing study results.

\section{RESULTS}

Table 2 presents the descriptive values (means, standard deviations, and correlations) for the total sample. Table 3 presents the results of the regression analyses to test hypotheses 1, 2 and 3 .

Insert Tables 2 and 3 about here

Hypothesis 1 proposed that perceived pressures from both primary and secondary stakeholder groups are similar in Denmark, Germany, and the Netherlands. In respect to perceived primary stakeholder pressures (model 1a), Danish firms have lower scores $(\beta=-0.20$, $\mathrm{p}<0.01)$ than Dutch and German firms which have similar scores $(\beta=0.02$, n.s. $)$. In respect to perceived secondary stakeholder pressures (model 1b), Danish firms have higher scores $(\beta=$ 
$0.20, \mathrm{p}<0.01)$ and German firms have lower scores $(\beta=-0.14, \mathrm{p}<0.01)$ than Dutch firms. In summary, hypothesis 1 is partially supported for primary stakeholders and not supported for secondary stakeholder pressures.

Hypothesis 2 proposed that the implementation of community $\mathrm{CR}$ and environmental $\mathrm{CR}$ practices would be positively related to perceived pressures from primary stakeholder groups (H2a) and secondary stakeholder groups (H2b). Consistent with hypothesis 2, the implementation of community $\mathrm{CR}$ practices is positively related to perceived primary stakeholder pressure $(\beta=0.31, \mathrm{p}<0.001$; model $2 \mathrm{~b})$ and perceived secondary stakeholder pressure $(\beta=0.35, \mathrm{p}<0.001 ;$ model $2 \mathrm{c})$. Similarly, implementation of environmental CR practices is positively related to perceived primary stakeholder pressures $(\beta=0.34, p<0.001$; model 3b) and perceived secondary stakeholder pressures $(\beta=0.26, \mathrm{p}<0.001$; model 3c). Hence, hypothesis 2 is fully supported. However, we also find some country differences in the strength of these positive relationships between perceived stakeholder pressures and CR practice implementation. Specifically, the positive relationship between secondary stakeholder pressures and community CR practices is marginally stronger in Germany than in Denmark and the Netherlands $(\beta=0.09, \mathrm{p}<0.10$, model $2 \mathrm{c})$, and the positive relationship between primary stakeholder pressures and environmental CR practices is also stronger in Germany than in Denmark and the Netherlands $(\beta=0.14, \mathrm{p}<0.01$; model $3 \mathrm{~b})$.

Hypothesis 3 proposed that the implementation of community CR and environmental CR practices would be similar in Denmark, Germany, and the Netherlands. Hypothesis 3 is fully supported given that there are no significant country differences in the implementation of community CR practices (model 2a) or environmental CR practices (model 3a). 
Table 4 presents the hierarchical regression results to test hypotheses 4 and 5 . Consistent with hypothesis $4 \mathrm{a}$, corporate reputation is positively related to the implementation of community $\mathrm{CR}(\beta=0.26, \mathrm{p}<0.001)$ and environmental CR practices $(\beta=0.49, \mathrm{p}<0.001$; model 1b). Mixed support is found for hypothesis $4 \mathrm{~b}$ with financial performance being positively related to community $\mathrm{CR}$ practices $(\beta=0.17, \mathrm{p}<0.001)$, but not being significantly related to environmental CR practices $(\beta=0.07$, model $2 b)$.

Consistent with Hypothesis 5a, there are no significant country differences in the positive relationships between community and environmental CR practices with corporate reputation (model 1c). Hypothesis $5 \mathrm{~b}$ is also supported (model 2c).

Insert Table 4 about here

Hypothesis 6 proposed that there would be a synergistic effect between the implementation of community and environmental CR practices and business outcomes. As shown in Table 4, there is a significant interaction between these two types of CR practices and corporate reputation $(\beta=-0.10, p<0.01$; model $1 \mathrm{~d})$ with no significant country differences in this interaction. We illustrated the significant interaction of the total sample using procedures identified by Cohen et al. (2003). As shown in Figure 2, firms with high levels of environmental CR (+1 s.d.) have the highest corporate reputation irrespective of the level of community CR practices. However, for firms with low levels of environmental CR (-1 s.d.), those with high community CR have significantly higher corporate reputations than those with lower levels of community CR.

In respect to financial performance, the community CR-by-environmental CR two-way interaction is not significant $(\beta=0.02$; model $2 \mathrm{~d}$ ) but there is a significant three-way country 
interaction for Germany $(\beta=0.13, p<0.05$; model $2 \mathrm{~d})$. The nature of this interaction for the German sample is illustrated in Figure 3 which shows that the financial performance of firms with low levels of environmental CR is similar whereas German firms with high levels of community $\mathrm{CR}$ and environmental $\mathrm{CR}$ have significantly higher financial performance than firms with low community CR and high environmental CR. In summary, hypothesis 6 is partially supported in respect to the synergistic effects of high levels of community and environmental CR practices on the financial performance of German firms, but not for Danish and Dutch firms.

Insert Figures 2 and 3 about here

Our control variables reveal mixed results. The degree of internationalization and the ownership form have no effect on perceived stakeholder pressure and CSER practices (Table3). However, we found a significant positive effect of company size on environmental CR practices. Moreover, there is a strong industry effect, i.e. manufacturing and resource-based firms show significantly higher scores for environmental CR than service firms. For MNCs, the relationship between CSER practices and corporate reputation is significantly negative and the relationship with financial performance significantly positive, while the other three control variables have no performance effect (Table 4).

\section{DISCUSSION AND CONCLUSIONS}

The purpose of this study was to analyze the impact of stakeholder pressures on CSER practices and outcomes and to reveal potential similarities and differences among European countries. We addressed these questions by focusing on the antecedents, prevalence, and outcomes of CSER practices in Denmark, Germany, and the Netherlands. In general, the data supports our 
argumentation that strong stakeholder pressures lead to distinct CSER practices which in turn increase business outcomes. One exception is the finding that environmental CR has no significant effect on financial performance. A possible explanation for this is that environmental CR implies high investments in technologies, green products, and production processes. While their announcement may have an immediate effect on corporate reputation, it takes much longer before these investments pay-off financially. Thus, future studies should consider possible timelags between the introduction of CSER practices and outcomes and analyze not only if but also when CSER pays (Gunningham, 2009). Moreover, potential curvilinear relationships between environmental CR and financial performance may be explored. There is evidence that although socially conscious stakeholders are willing to sacrifice part of their financial wealth to support firms that emphasize CSER, they nevertheless expect reasonable returns from their financial or human capital investments (McWilliams and Siegel, 2001). With successive increases in CSER efforts beyond a sufficiently high level, these stakeholders may become unwilling to accept terms that continue to lower their financial returns, and thus start to withdraw from investing their resources in the firm. Therefore, the marginal benefit of CSER activities may be expected to decrease as the costs that are associated with these activities increase (Barnett and Salomon, 2006; Wang, Choi, and Li, 2008).

We also found strong support for our second line of argumentation based on institutional theory that similar institutional conditions lead to similar stakeholder pressures, CSER practices and business outcomes. One exception is Denmark where firms perceive lower pressure from primary and higher pressure from secondary stakeholders than firms in Germany and the Netherlands. The higher pressures from secondary stakeholders in Denmark may be explained by the extensive fiscal interventions of the government in labor markets and relatively strong labor 
unions which are typical for Northern European countries. Moreover, social partnerships between private firms and non-profit organizations to address problems of social exclusion and unemployment have become a specific characteristic of CSER in Denmark since 1995 and are still the predominant CSER issue in this country (Morsing, 2005). In contrast, CSER activities in Germany and the Netherlands are more market-driven, i.e. mostly evoked by customers, suppliers and employees. As is typical for continental European countries, no explicit laws for CSER or concerted actions between governments, firms and NGOs exist (Habisch and Wegner, 2005; Midttun et al., 2006).

Finally, we found some country differences with regard to the proposed interaction effects between CSER practices and business outcomes. In Germany, environmental CR only has a positive impact on financial performance if companies are also engaged in community CR. In companies where community $\mathrm{CR}$ practices are less pronounced, environmental CR even has a negative effect on financial performance. In such a situation, the marginal costs of increased environmental CR are obviously higher than their marginal value for companies. Future studies should analyze whether this effect is caused by cultural differences (e.g., by the higher degree of institutional collectivism in Germany compared to Denmark and the Netherlands), differences in the regulatory environment, or income differences.

\section{CONTRIBUTIONS, IMPLICATIONS AND LIMITATIONS}

\subsection{Contributions to institutional theory and international CSER research}

This study enhances the state of knowledge in the area of international CSER in numerous ways. As relatively little empirical large-scale cross-country research exists, our study makes a contribution investigating country similarities and differences with regard to antecedents and outcomes of CSER practices in Denmark, Germany, and the Netherlands. With the selection of 
these countries we also contribute to the literature on CSER in countries with similar institutional frameworks, thus responding to Matten and Moon's (2008: 419) call for 'more fine-grained comparisons' in cross-national CSER research.

First, our study contributes to institutional theory by specifying the mechanisms with which national institutions influence the implementation of CSER practices, namely by financial and non-financial rewards. We show that isomorphic pressures lead to primary and secondary stakeholder pressures, CSER practices, and positive business outcomes. Firms that respond to the pressures from relevant stakeholders with adequate CSER practices will improve their corporate reputation and financial performance. Thus our study also supports the argumentation of the stakeholder approach that a firm needs the support of all legitimate stakeholders to realize its goals.

Second, we demonstrate that institutional theory can explain country similarities in CSER practices and outcomes in countries with similar political, financial, educational, and labor systems. We find that the mechanisms that link institutional pressures with CSER activities are mostly consistent in the three European countries in our study, thus supporting the arguments of Matten and Moon (2008) for a pan-European approach of CSER. Primary and secondary stakeholder interests are similar in countries with similar institutional environments. Thus, stakeholder pressures on firms to act in an ecologically and socially responsible way can be traced back to isomorphic pressures.

Despite many similarities, some differences exist as well. For example, we find mixed results for the strength of these relationships in the three countries in our study. Danish firms perceive lower pressure from primary and higher pressure from secondary stakeholders than firms from Germany and the Netherlands. Moreover, the interaction effects between community 
$\mathrm{CR}$, environmental $\mathrm{CR}$, and financial performance differ between the three countries. Thus, the study shows that the effects of institutional conditions on stakeholder pressures, CSER practices, and business outcomes are not consistent. In particular, the mechanisms that link institutional pressures with CSER practices may differ for community CR and environmental CR. Future research should therefore analyze these mechanisms in more detail.

\subsection{Implications for policy and organizations}

The study also has several implications for managers and policy makers. The results reveal that relevant stakeholders are able to improve social and environmental practices by exerting institutional pressure. Many firms regard this pressure as a disadvantage as it incurs costs, e.g., implementing green technologies or considering social aspects in HRM. While industry managers often argue that these measures decrease international competitiveness, our study shows that it can lead to higher business outcomes, i.e., social and ecological responsibility pays off. Firms that are pressured by stakeholders to implement environmental and social practices are more profitable.

Our data reveal that this does not only apply to pressures from primary stakeholders such as customers, employees, financial institutions, and suppliers, but also to secondary stakeholders that are affected by its activities. Governments and NGOs, for example, not only pressure firms to act in a socially and environmentally responsible way by regulating their conditions or by influencing the public opinion, but this behavior may also result in positive business outcomes.

A good example is renewable energy firms in Germany. The German government was one of the first to implement strict environmental regulations. Furthermore, demanding customers continuously pressure German firms into innovation and product improvement. These pressures helped German firms to reach a leading position in the world market for renewable 
energies and allowed them to export their products successfully to other countries. Our study reveals that similar effects may be expected when firms are pressured to implement measures that help to protect the environment or that increase their social responsibility and support, for example, the position of the German government in the recent debate on electro-mobility and accelerated nuclear phase-out.

\subsection{Limitations and directions for future research}

When interpreting our results, some limitations have to be considered. Although we undertook several preventive and statistical measures to address common method variance concerns (Podsakoff et al., 2003), our study relies exclusively on survey self-report and cross-sectional data. Hence we have to consider the potential of bias. Social desirability in reporting a firm's community $\mathrm{CR}$ and environmental $\mathrm{CR}$ practices may be one potential bias, despite the assurance of anonymity of respondents in order to avoid this issue. While cross-country differences in response styles (Harzing, 2006) are a potential concern, our investigation of the measurement and configural invariances between Danish, German and Dutch responses indicate that this concern is not relevant for our study.

Although this study included samples from three different European countries, additional countries may be needed to confirm our findings of antecedents and outcomes of CSER practices in countries with similar economic and political conditions. Another avenue for future research may be to analyze how changes in the institutional environment affect the variables in our study. This longitudinal approach would further enhance our understanding of the relationships between stakeholder pressures, CSER practices and business outcomes and how these develop over time. 


\section{REFERENCES}

Aguinis H, Glavas A. (2012). What we know and don't know about corporate social responsibility: a review and research agenda. Journal of Management 38(4): 932-968.

Angus-Leppan T, Metcalf L, Benn S. (2010). Leadership styles and CSR practice: an examination of sensemaking, institutional drivers and CSR leadership. Journal of Business Ethics 93(2): 189-213.

Bagozzi RP, Yi Y. (1988). On the evaluation of structural equation models. Journal of the Academy of Marketing Science 16: 74-94.

Barnett ML, Salomon RM. (2006). Beyond dichotomy: the curvilinear relationship between social responsibility and financial performance. Strategic Management Journal 27(11): 1101-1122.

Boiral O. (2007). Corporate greening through ISO 14001: a rational myth? Organization Science 18(1): 127-146.

Bondy K, Matten D, Moon J. (2004). The adoption of voluntary codes of conduct in MNCs: a three-country comparative study. Business and Society Review 109(4): 449-477.

Brammer SJ, Millington A. (2008). Does it pay to be different? An analysis of the relationship between corporate and social performance. Strategic Management Journal 29(12): 13251342.

Brammer SJ, Pavlin S. (2006). Corporate reputation and social performance: the importance of fit. Journal of Management Studies 43(3): 435-455.

Brewer T. (2008). Climate change technology transfer: a new paradigm and policy agenda. Climate Policy 8(5): 516-526.

Brown TJ, Dacin PA. (1997). The consumer and the product: corporate associations and consumer product responses. Journal of Marketing 61(1): 68-84.

Buysse K, Verbeke A. (2003). Proactive environmental strategies: a stakeholder management perspective. Strategic Management Journal 24(5): 453-470.

Campbell JL. (2007). Why should corporations behave in socially responsible ways? An institutional theory of corporate social responsibility. Academy of Management Review 32(3): 946-967.

Chatterji AK, Toffel MW. (2010). How firms respond to being rated. Strategic Management Journal 31(9): 917-945. 
Cheung GW, Rensvold RB. (2002). Evaluating goodness-of-fit indexes for testing measurement invariance. Structural Equation Modeling 9: 233-255.

Clarkson MBE. (1995). A stakeholder framework for analyzing and evaluating corporate social performance. Academy of Management Review 20: 92-117.

Cohen J, Cohen P, West SG, Aiken LS. (2003. Applied multiple regression/correlation analysis for the behavioral sciences (3rd ed). Lawrence Erlbaum Associates: Mahwah, NJ.

Collier J, Esteban R. (2007). Corporate social responsibility and employee commitment. Business Ethics 16: 19-33.

CSR Europe. (2007). The European Alliance for CSR. CSR Europe: Brussels.

CSR-IMPACT. (2010). CSR - delivering benefits for the economy and society at large? Available at: http://www.csr-impact.eu/about.html [14 July 2014].

Cycyota CS, Harrison DA. (2006). What (not) to expect when surveying executives: a metaanalysis of top manager response rates and techniques over time. Organizational Research Methods 9(2): 133-160.

De Boer J. (2003). Sustainability labeling schemes: the logic of their claims and their functions for stakeholders. Business Strategy and the Environment 12: 254-264.

DiMaggio PJ, Powell WW. (1983). The iron cage revisited: institutional isomorphism and collective rationality in organizational fields. American Sociological Review 48(2): 147-160.

Doh JP, Guay TR. (2006). Corporate social responsibility, public policy and NGO activism in Europe and the United States: an institutional-stakeholder perspective. Journal of Management Studies 43(1): 47-73.

Egri CP, Hornal RC. (2002). Strategic environmental human resource management and perceived organizational performance: An explanatory study of the Canadian manufacturing sector. In Research in Corporate Sustainability: The Evolving Theory and Practice of Organizations in the Natural Environment, Sharma S, Strarik M (eds.). Edward Elgar Publishing: Northampton, MA: 205-236.

Egri CP, Ralston DA. (2008) Corporate responsibility: a review of international management research from 1998 to 2007. Journal of International Management 14(4): 319-339.

European Commission. (2007). Corporate Social Responsibility. National Public Policies in the European Union. Office for Official Publications of the European Communities: Luxembourg.

Fischer R. (2004). Standardization to account for cross-cultural response bias: a classification of 
score adjustment procedures and review of research in JCCP. Journal of Cross-Cultural Psychology 35: 263-282.

Flammer C. (2013).Corporate social responsibility and shareholder reaction: the environmental awareness of investors. Academy of Management Journal 56(3): 758-781

Florida R, Davison D. (2001). Gaining from green management: environmental management systems inside and outside the factory. California Management Review 43: 64.

Fombrun C, Shanley M. (1990). What's in a name? Reputation building and corporate strategy. Academy of Management Journal 33(2): 233-258.

Fombrun CJ, Gardberg NA, Sever J. (2000). The reputation quotient: a multi-stakeholder measure of corporate reputation. Journal of Brand Management 7(4): 241-255.

Furrer O, Egri CP, Ralston DA, Danis W, Reynaud E, Naoumova I, Molteni M, Starkus A, Darder FL, Dabic M, Furrer-Perrinjaquet A. (2010). Attitudes toward corporate responsibilities in Western Europe and in Central and Eastern Europe. Management International Review 50(3): 379-398.

Greening DW, Gray B. (1994). Testing a model of organizational response to social and political issues. Academy of Management Journal 37(3): 467-498.

Gunningham N. (2009). Shaping corporate environmental performance: a review. Environmental Policy and Governance 19: 215-231.

Habisch A, Jonker J, Wegner M, Schmidpeter R (eds.). (2005). Corporate Social Responsibility across Europe. Berlin: Springer.

Habisch A, Wegner M. (2005). Germany - overcoming the heritage of corporatism. In Corporate Social Responsibility across Europe, Habisch A, Jonker J, Wegner M, Schmidpeter R (eds.). Berlin: Springer: 111-123.

Hanges PJ, Shteynberg G. (2004). Methodological challenges and solutions for leadership researcher. German Journal of Human Resource Research 18(3): 346-358.

Hart S. (1995). A natural resource-based view of strategy. Academy of Management Review 20: 986-1014.

Harzing A-W. (2006). Response styles in cross-national survey research: a 26-country study. International Journal of Cross Cultural Management 6(2): 243-266.

Hiss S. (2009). From implicit to explicit corporate social responsibility. Business Ethics Quarterly 19(3): 433-451. 
Holtbrügge D, Berg N, Puck J. (2007). To bribe or to convince? Political stakeholders and political activities in German multinational corporations. International Business Review 16(1): 47-67.

Holtbrügge D, Dögl C. (2012). How international is corporate social responsibility? A literature review. Journal of International Management 18(2): 180-195.

Husted BW, Allen DB. (2006). Corporate social responsibility in the multinational enterprise: strategic and institutional approaches. Journal of International Business Studies 37: 838489.

Inglehart R. (1997). Modernization and Postmodernization: Cultural, Economic, and Political Change in 43 Societies. Princeton: Princeton University Press.

Jackson G, Apostolakou A. (2010). Corporate social responsibility in Western Europe: an institutional mirror or substitute? Journal of Business Ethics 94: 371-394.

Jennings PD, Zandbergen PA. 1995). Ecologically sustainable organizations: an institutional approach. Academy of Management Review 20(4): 1015-1052.

Jiang RJ, Bansal P. (2003. Seeing the need for ISO 14001. Journal of Management Studies 40(4):1047-1067.

Johnson T, Kulesa P, Cho YI, Shavitt S. (2005). The relation between culture and response styles: evidence from (19 countries. Journal of Cross-Cultural Psychology 36: 264-277.

Kassinis G, Vafeas N. (2006). Stakeholder pressures and environmental performance. Academy of Management Journal 49(1): 145-159.

Kolk A. (2005). Environmental reporting by multinationals from the Triad: convergence or divergence? Management International Review. Special Issue 1 45: 145-167.

Kolk A. (2008). Sustainability, accountability and corporate governance: exploring multinationals' reporting practices. Business Strategy and the Environment 17(1): 1-15.

Maignan I, Ferrell OC, Hult TG. (1999). Corporate citizenship: cultural antecedents and business benefits. Journal of the Academy of Marketing Science 27(4): 455-469.

Maignan I, Ferrell OC. (2003). Nature of corporate responsibilities: perspectives from American, French, and German consumers. Journal of Business Research 56(1): 55-67.

Maignan I, Ralston DA. (2002). Corporate social responsibility in Europe and the U.S.: insights from business' self-presentations. Journal of International Business Studies 33(3): 797-514.

Marquis C, Glynn MA, Davis GF. (2007). Community isomorphism and corporate social action. 
Academy of Management Review 23(3): 925-945.

Matten D, Moon J. (2008). 'Implicit' and 'explicit' CSR: a conceptual framework for a comparative social responsibility. Academy of Management Review 33(2): 404-424.

McWilliams A, Siegel D. (2001. Corporate social responsibility: a theory of the firm perspective. Academy of Management Review 26(1): 117-121.

Meyer JW, Rowan B. (1977). Institutional organizations: formal structures as myth and ceremony. American Journal of Sociology 80: 340-363.

Midttun A, Gautesen K, Gjølberg M. (2006). The political economy of CSR in Western Europe. Corporate Governance 6(4): 369-385.

Morsing M. (2005). Denmark - inclusive labour market strategies. In Corporate Social Responsibility across Europe, Habisch A, Jonker J, Wegner M, Schmidpeter R (eds.). New York: Springer.

Navarro P. (1988). Why do corporations give to charity? Journal of Business Ethics 61(1): 6593.

Orlitzky M, Schmidt FL, Rynes SL. (2003). Corporate social and financial performance: a metaanalysis. Organization Studies 24: 403-441.

Peters A. (2009). Pathways out of the Crisis: CSR as a Strategic Tool for the Future. Gütersloh, DE: Bertelsmann Foundation.

Podsakoff PM, MacKenzie SB, Podsakoff NP, Lee J-Y. (2003). Common method biases in behavioral research: a critical review of the literature and recommended remedies. Journal of Applied Psychology 88: 879-903.

Prahalad CK. (2006). The Fortune at the Bottom of the Pyramid. Upper Saddle River: Wharton School Publishers.

Preuss L, Haunschild A, Matten D. (2009). The rise of CSR: implications for HRM and employee representation. International Journal of Human Resource Management 20(4): 953-973.

Rasche, A. (2015). The corporation as a political actor - European and North American perspectives. European Management Journal 33(1): 4-8.

Rugman AM, Verbeke A. (1998). Corporate strategies and environmental regulations: an organizing framework. Strategic Management Journal 19: 363-375.

Russo MV, Fouts PA. (1997). A resource-based perspective on corporate environmental 
performance and profitability. Academy of Management Journal 40(3): 534-559.

Samiee S, Roth K. (1992). The influence of global marketing standardization on performance. Journal of Marketing 56(2): 1-17.

Scott WR. (1992). Organizations: Rational, Natural, and Open Systems. Englewood Cliffs, NJ: Prentice-Hall.

Sen S, Bhattacharya CB. (2001). Does doing good always lead to doing better? Consumer reactions to corporate social responsibility. Journal of Marketing Research 38: 225-243.

Sharma S. (2000). Managerial interpretations and organizational context as predictors of corporate choice of environmental strategy. Academy of Management Journal 43:681-697.

Sison A. (2009). From CSR to corporate citizenship: Anglo-American and continental European perspectives. Journal of Business Ethics 89: 235-246.

Steenkamp J-BEM, Baumgartner H. (1998). Assessing measurement invariance in cross-national consumer research. Journal of Consumer Research 25: 78-90.

Ungericht B, Hirt C. (2010). CSR as a political arena: the struggle for a European framework. Business and Politics 12(4): 1-22.

Waddock SA, Bodwell C, Graves SB. (2002). Responsibility: the new business imperative. Academy of Management Executive 16(2): 132-148.

Waddock SA, Graves SB. (1997). The corporate social performance-financial performance link. Strategic Management Journal 18(4): 303-319.

Wang H, Choi J, Li J. (2008). Too little or too much? Untangling the relationship between corporate philanthropy and firm financial performance. Organization Science 19(1): 143159.

Williams LJ, Edwards JR, Vandenberg RJ. (2003). Recent advances in causal modeling methods for organizational and management research. Journal of Management 29: 903-936.

Wright P, Ferris S. (1997). Agency conflict and corporate strategy: the effect of divestment on corporate value. Strategic Management Journal 18: 77-83.

Yale Center for Environmental Law and Policy \& Center for International Earth Science Information Network Columbia University. (2005). 2005 Environmental Sustainability Index. Benchmarking National Environmental Stewardship. Yale University: Boston. Available at: http://www.yale.edu/esi/ESI2005_Main_Report.pdf [18 April 2015].

Yang Z, Wang X, Su C. (2006). A review of research methodologies in international business. 
International Business Review 15(6): 601-617. 
FIGURE 1

Research model

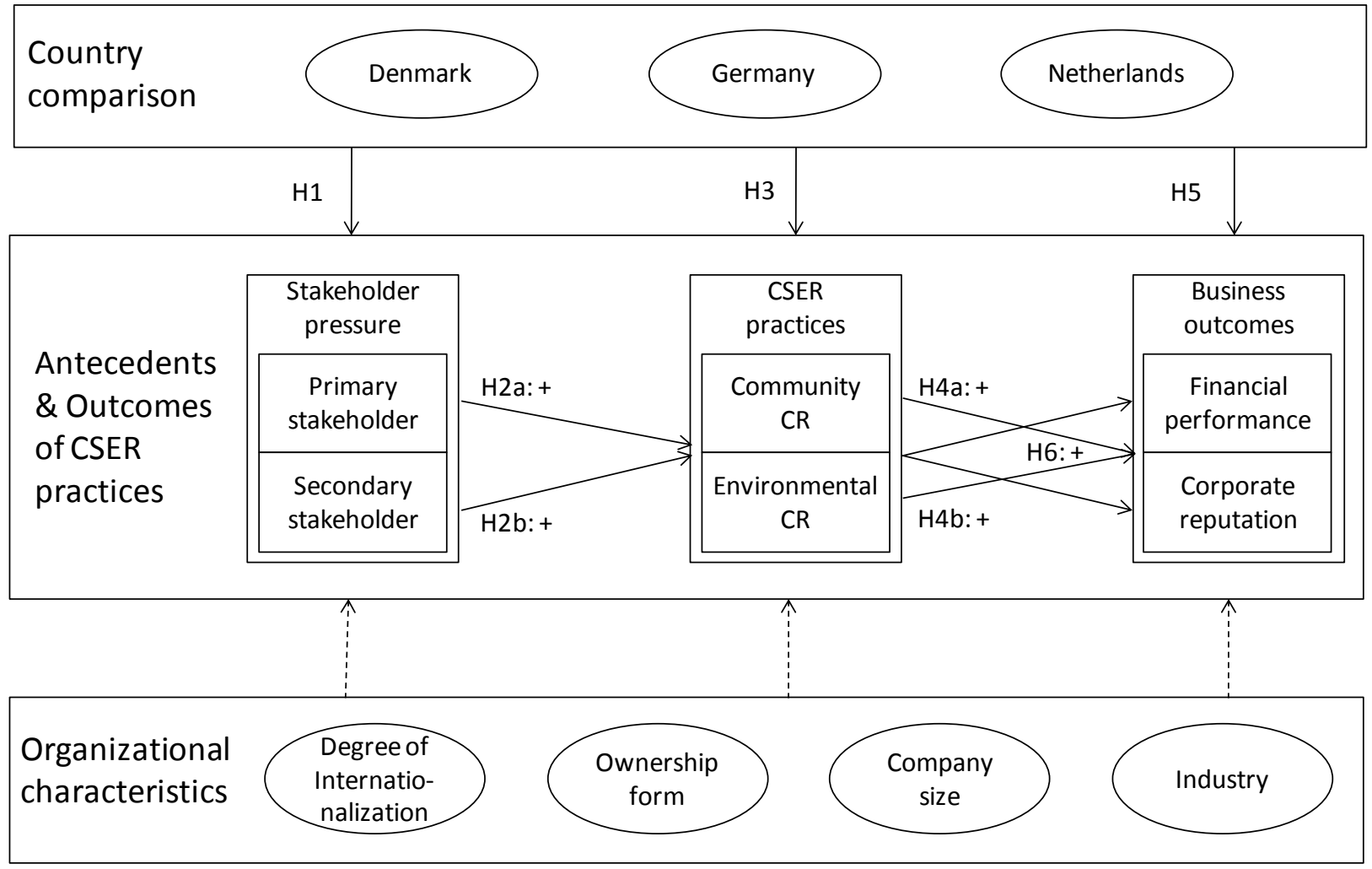


TABLE 1

Country measures: Means, standard deviations, and scale reliabilities (Raykov's $\rho$ ) a

\begin{tabular}{lccccccccccc}
\hline & \multicolumn{3}{c}{ Denmark } & \multicolumn{3}{c}{ Germany } & \multicolumn{3}{c}{ Netherlands } \\
\cline { 2 - 10 } & Mean & s.d. & $\rho$ & Mean & s.d. & $\rho$ & Mean & s.d. & $\rho$ \\
\hline Primary stakeholder pressures & 3.09 & $(0.35)$ & 0.64 & 3.21 & $(0.37)$ & 0.81 & 3.27 & $(0.38)$ & 0.74 \\
Secondary stakeholder pressures & 2.79 & $(0.50)$ & 0.64 & 2.62 & $(0.48)$ & 0.72 & 2.69 & $(0.60)$ & 0.80 \\
Community CR & 4.92 & $(1.84)$ & 0.88 & 4.79 & $(2.13)$ & 0.84 & 5.09 & $(1.99)$ & 0.90 \\
Environmental CR & 4.88 & $(1.92)$ & 0.87 & 4.79 & $(2.13)$ & 0.82 & 5.32 & $(1.94)$ & 0.85 \\
Corporate reputation & 7.67 & $(0.29)$ & 0.82 & 7.69 & $(0.30)$ & 0.78 & 7.71 & $(0.26)$ & 0.76 \\
Financial performance & 6.39 & $(1.30)$ & 0.85 & 6.49 & $(1.23)$ & 0.90 & 6.22 & $(1.18)$ & 0.85 \\
\hline
\end{tabular}

a Denmark $\mathrm{N}=201$, Germany $\mathrm{N}=138$, Netherlands $\mathrm{N}=180$ 
TABLE 2

Descriptive statistics: Means, standard deviations, and correlations a, b

\begin{tabular}{|c|c|c|c|c|c|c|c|c|c|c|c|c|c|c|}
\hline & & Mean & s.d. & 1 & 2 & 3 & 4 & 5 & 6 & 7 & 8 & 9 & 10 & 11 \\
\hline 1. & Denmark & & & & & & & & & & & & & \\
\hline 2. & Germany & & & & & & & & & & & & & \\
\hline 3. & Primary stakeholders & 3.28 & 0.66 & 0.34 & 0.13 & & & & & & & & & \\
\hline 4. & Secondary stakeholders & 2.60 & 0.75 & 0.41 & -0.01 & 0.45 & & & & & & & & \\
\hline 5. & Community CR & 4.93 & 1.90 & -0.04 & -0.05 & 0.21 & 0.27 & & & & & & & \\
\hline 6. & Environmental CR & 4.99 & 2.01 & -0.07 & -0.10 & 0.24 & 0.23 & 0.44 & & & & & & \\
\hline & Corporate reputation & 7.70 & 0.86 & -0.01 & 0.18 & 0.11 & -0.03 & 0.18 & 0.24 & & & & & \\
\hline & Financial performance & 6.35 & 1.67 & 0.00 & 0.05 & 0.08 & 0.05 & 0.17 & 0.17 & 0.31 & & & & \\
\hline & $\mathrm{MNC}$ & 0.61 & 0.48 & -0.02 & -0.12 & 0.01 & 0.08 & 0.04 & 0.18 & -0.01 & 0.13 & & & \\
\hline & Publicly traded & 0.39 & 0.48 & 0.51 & -0.02 & 0.14 & 0.26 & -0.01 & 0.00 & -0.07 & -0.02 & 0.09 & & \\
\hline 11. & Company size & 2.07 & 0.79 & -0.01 & -0.01 & 0.02 & 0.10 & 0.09 & 0.20 & -0.04 & 0.05 & 0.35 & 0.11 & \\
\hline 12. & Industry: Services & 0.39 & 0.48 & -0.12 & -0.10 & -0.14 & -0.08 & -0.05 & -0.18 & -0.02 & -0.03 & -0.18 & -0.07 & -0.05 \\
\hline
\end{tabular}

a Total sample N = 519 (201 Denmark, 138 Germany, 180 Netherlands). Categorical variables coded: countries are effect coded with Netherlands as reference category; scope of operations: $1=$ MNC, $0=$ domestic-only; ownership status: $1=$ publicly traded, $0=$ privately held and other; company size: 1 = less than 100 employees, $2=100-999$ employees, $3=1000$ employees or more; industry: $1=$ services, $0=$ manufacturing and resource-based

${ }_{b}$ Correlations $r \geq|0.09|$ are significant at the $\mathrm{p}<0.05$ level, $\mathrm{r} \geq|0.12|$ significant at $\mathrm{p}<0.01$ level, $\mathrm{r} \geq|0.15|$ significant at $\mathrm{p}<0.001$ level. 
TABLE 3

Regression results: Perceived stakeholder pressures and CSER practices

\begin{tabular}{|c|c|c|c|c|c|c|c|c|c|c|}
\hline \multirow[b]{3}{*}{ Variables $^{\mathrm{a}}$} & \multicolumn{2}{|c|}{$\begin{array}{l}\text { Stakeholder } \\
\text { pressures }\end{array}$} & \multirow{2}{*}{\multicolumn{4}{|c|}{ Community CR }} & \multirow{2}{*}{\multicolumn{4}{|c|}{ Environmental CR }} \\
\hline & Primary & Secondary & & & & & & & & \\
\hline & $1 \mathrm{a}$ & $1 \mathrm{~b}$ & $2 \mathrm{a}$ & $2 b$ & $2 \mathrm{c}$ & $2 \mathrm{~d}$ & $3 a$ & $3 b$ & $3 c$ & $3 d$ \\
\hline $\mathrm{MNC}$ & 0.05 & 0.02 & 0.00 & -0.01 & -0.00 & -0.02 & 0.07 & 0.05 & 0.06 & 0.03 \\
\hline Publicly traded & -0.05 & -0.09 & -0.03 & -0.01 & 0.00 & 0.04 & -0.01 & -0.00 & 0.01 & 0.05 \\
\hline Company size & -0.07 & 0.08 & 0.06 & 0.08 & 0.03 & 0.05 & $0.16 * * *$ & $0.18 * * *$ & $0.14 * * *$ & $0.16 * * *$ \\
\hline Industry: Services & $-0.09 *$ & -0.00 & -0.04 & -0.01 & -0.03 & 0.00 & $-16 * * *$ & $-0.12 * *$ & $-0.16 * * *$ & $-0.10 * *$ \\
\hline Denmark & $-0.20 * *$ & $0.20 * *$ & 0.01 & 0.08 & -0.06 & 0.00 & -0.05 & 0.00 & -0.11 & -0.05 \\
\hline Germany & 0.02 & $-0.14 * *$ & -0.06 & -0.08 & -0.00 & -0.00 & -0.08 & $-0.10^{*}$ & -0.04 & -0.04 \\
\hline $\begin{array}{l}\text { Primary stakeholders } \\
\text { Primary stakeholders }\end{array}$ & & & & $0.31 * * *$ & & $0.49 * * *$ & & $0.34 * * *$ & & $0.50 * * *$ \\
\hline x Denmark & & & & 0.04 & & 0.01 & & -0.01 & & -0.02 \\
\hline $\begin{array}{l}\text { Primary stakeholders } \\
\text { x Germany }\end{array}$ & & & & 0.02 & & 0.02 & & $0.14 * *$ & & $0.11 *$ \\
\hline Secondary stakeholders & & & & & $0.35^{* * *} *$ & $0.51 * * *$ & & & $0.26 * * *$ & $0.43 * * *$ \\
\hline $\begin{array}{l}\text { Secondary stakeholders } \\
\text { x Denmark }\end{array}$ & & & & & -0.02 & -0.03 & & & 0.08 & 0.05 \\
\hline $\begin{array}{l}\text { Secondary stakeholders } \\
\text { x Germany }\end{array}$ & & & & & $0.09^{\dagger}$ & $0.09^{\dagger}$ & & & -0.07 & -0.03 \\
\hline$\Delta \mathrm{R}^{2}$ & & & & $0.096 * * *$ & $\begin{array}{l}0.112 * * \\
*\end{array}$ & & & $0.119 * * *$ & $0.077 * * *$ & \\
\hline Model R 2 & 0.059 & 0.029 & 0.010 & 0.106 & 0.122 & 0.330 & 0.090 & 0.209 & 0.167 & 0.377 \\
\hline Model F & $5.35 * * *$ & $2.58 *$ & 0.83 & $6.69 * * *$ & $7.83 * * *$ & $17.94 * * *$ & $8.39 * * *$ & $14.95 * * *$ & $11.31 * * *$ & $22.05 * * *$ \\
\hline
\end{tabular}

${ }^{a}$ Country variables effect coded with the Netherlands as the reference category. 


$$
{ }^{\dagger} \mathrm{p}<0.10, * \mathrm{p}<0.05, * * \mathrm{p}<0.01, * * * \mathrm{p}<0.001
$$

TABLE 4

Hierarchical regression results: CSER practices and business outcomes

\begin{tabular}{|c|c|c|c|c|c|c|c|c|}
\hline & \multicolumn{4}{|c|}{ Corporate reputation } & \multicolumn{4}{|c|}{ Financial performance } \\
\hline & $1 \mathrm{a}$ & $1 b$ & $1 \mathrm{c}$ & $1 d$ & $2 \mathrm{a}$ & $2 b$ & $2 c$ & $2 \mathrm{~d}$ \\
\hline $\mathrm{MNC}$ & -0.03 & $-0.07 *$ & $-0.07^{*}$ & $-0.07 *$ & $0.13 * *$ & $0.13 * *$ & $0.13 * *$ & $0.13 * *$ \\
\hline Publicly traded & -0.03 & -0.01 & -0.02 & -0.02 & 0.01 & 0.02 & 0.01 & 0.01 \\
\hline Company size & $0.10 *$ & 0.00 & 0.00 & 0.00 & 0.06 & 0.04 & 0.04 & 0.04 \\
\hline Industry: Services & $-0.08^{\dagger}$ & 0.02 & 0.01 & 0.01 & 0.00 & 0.02 & 0.02 & 0.03 \\
\hline Denmark & -0.04 & -0.01 & -0.01 & -0.01 & -0.00 & -0.00 & 0.00 & 0.02 \\
\hline Germany & -0.01 & 0.04 & 0.04 & 0.04 & $0.09 \dagger$ & $0.11 *$ & $0.11^{*}$ & 0.07 \\
\hline Community $\mathrm{CR}$ & & $0.26 * * *$ & $0.26 * * *$ & $0.26 * * *$ & & $0.17 * * *$ & $0.17 * * *$ & $0.18 * * *$ \\
\hline Environmental CR & & $0.49 * * *$ & $0.49 * * *$ & $0.48 * * *$ & & 0.07 & $0.08^{\dagger}$ & $0.08^{\dagger}$ \\
\hline Community CR x Denmark & & & 0.04 & 0.03 & & & 0.03 & 0.01 \\
\hline Community CR x Germany & & & 0.02 & 0.01 & & & 0.01 & 0.01 \\
\hline Environmental CR x Denmark & & & -0.01 & -0.00 & & & -0.05 & -0.05 \\
\hline Environmental CR x Germany & & & -0.01 & -0.02 & & & -0.00 & 0.00 \\
\hline Community CR x Environmental CR & & & & $-0.10 * *$ & & & & 0.02 \\
\hline $\begin{array}{l}\text { Community CR x Environmental CR } \\
\text { x Denmark }\end{array}$ & & & & -0.01 & & & & -0.04 \\
\hline $\begin{array}{l}\text { Community CR x Environmental CR } \\
\text { x Germany }\end{array}$ & & & & -0.01 & & & & $0.13 *$ \\
\hline$\Delta \mathrm{R}^{2}$ & & $0.396 * * *$ & 0.003 & $0.011^{*}$ & & $\begin{array}{l}0.047 * * \\
*\end{array}$ & 0.003 & $0.011^{*}$ \\
\hline Model $\mathrm{R}^{2}$ & 0.018 & 0.415 & 0.418 & .429 & 0.036 & 0.083 & 0.086 & 0.097 \\
\hline Model F & 1.60 & $45.21 * * *$ & $30.30 * *$ & $\begin{array}{l}25.19 * * \\
*\end{array}$ & $3.19 * *$ & $5.76 * * *$ & $3.95 * * *$ & $3.59 * * *$ \\
\hline
\end{tabular}


${ }^{a}$ Country variables effect coded with the Netherlands as the reference category. ${ }^{\dagger} \mathrm{p}<0.10, * \mathrm{p}<0.05, * * \mathrm{p}<0.01, * * * \mathrm{p}<0.001$ 
FIGURE 2

Total sample: Corporate reputation, community $\mathrm{CR}$, and environmental CR

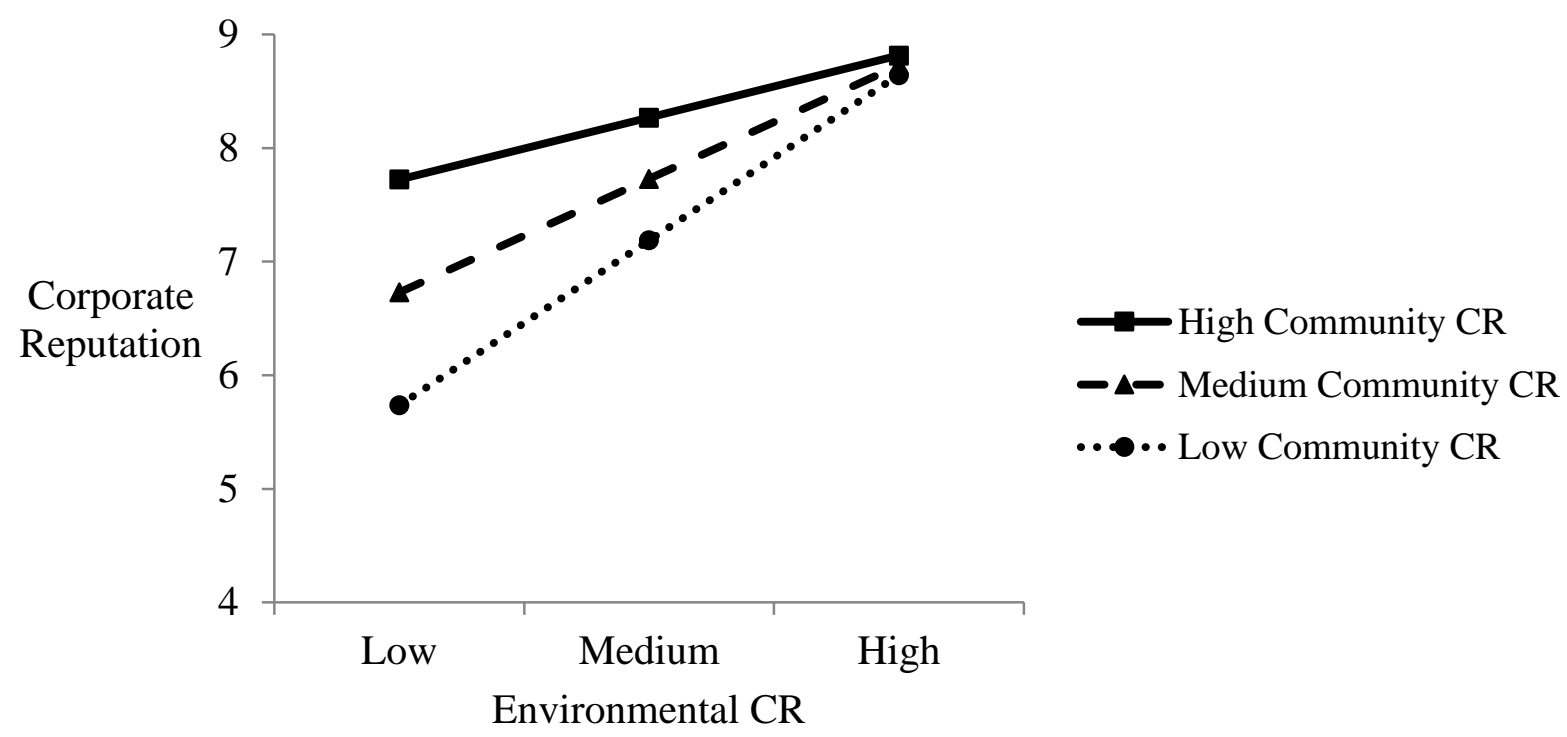

FIGURE 3

Germany: Financial performance, community $C R$, and environmental CR

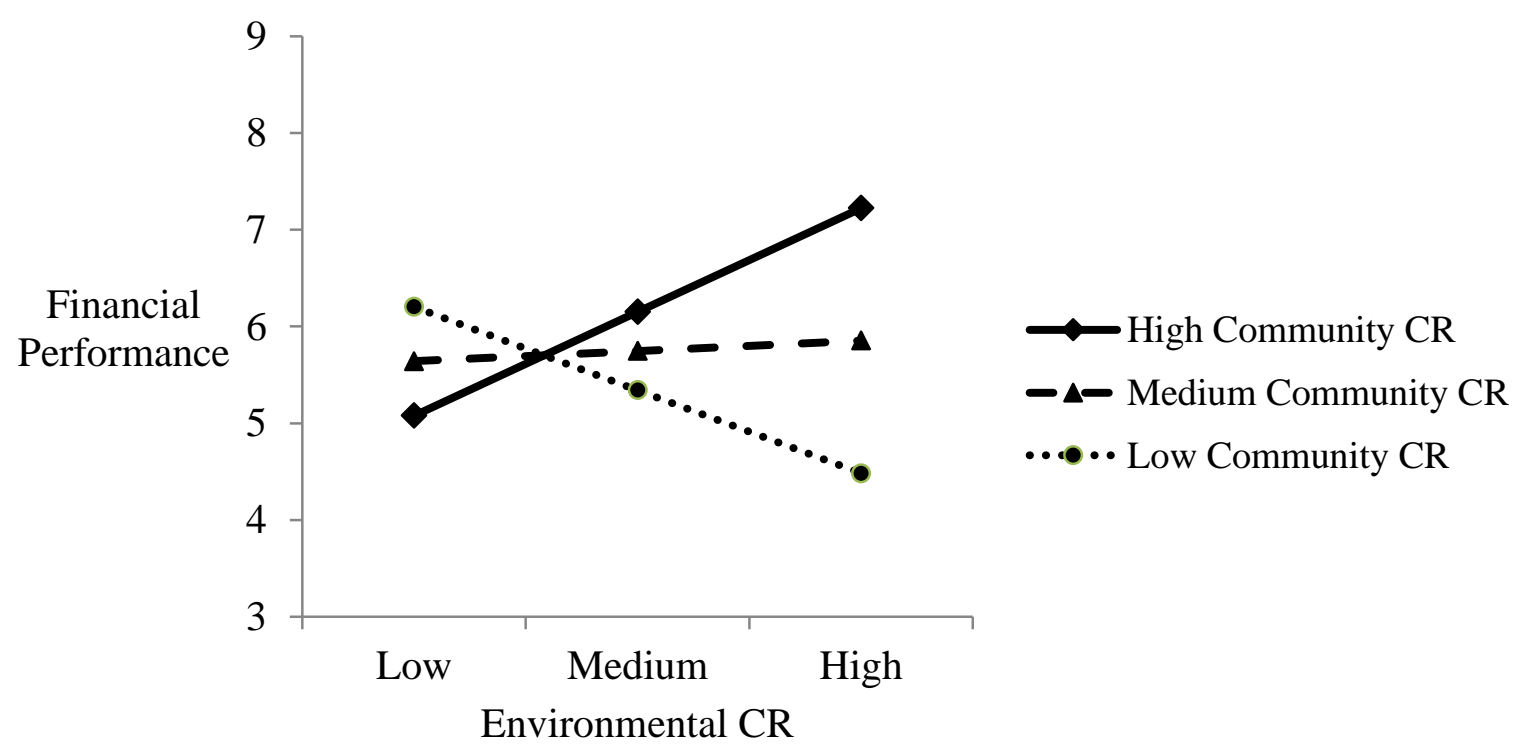

